\title{
Hatching phenology and voltinism of Heterocypris barbara (Crustacea: Ostracoda) from Lampedusa (Sicily, Italy)
}

\author{
Valeria ROSSI, ${ }^{*}$ Alessio MARTORELLA, Paolo MENOZZI \\ Dipartimento di Bioscienze, Università di Parma, viale G.P. Usberti 11/A, I-43124 Parma (Italy) \\ *Corresponding author: valeria.rossi@unipr.it
}

\begin{abstract}
The persistence of crustacean populations in ephemeral ponds requires appropriate adaptations in life history strategies (e.g. in hatching phenology). Organisms take advantage of pond filling when it occurs and hedge their bets for the possibility to complete one or more life cycles or to produce resting stages that ensure that the population will not go extinct. We carried out laboratory experiments to investigate the dynamics of a sexual population of Heterocypris barbara from a vernal pool in Lampedusa island (Sicily). Experimental organisms were obtained hydrating sediments from Aria Rossa temporary pond. Recruitment from resting eggs, voltinism, mean body size and sex ratio were observed in microcosms at different conductivities (high 2.0-2.7 $\mathrm{mS} \mathrm{cm}^{-1}$, intermediate 1.0-1.1 $\mathrm{mS} \mathrm{cm} \mathrm{cm}^{-1}$ and low

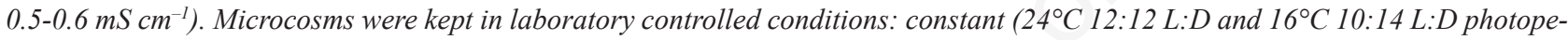
riod) or fluctuating thermal regimes. The experiment lasted 7 months. Resting and non-resting egg production and up to a bivoltine life cycle were observed. Recruitment events from egg bank and voltinism varied by thermal regime and conductivity. A prolonged recruitment phase occurred in conditions that could be considered a proxy of a rainy season $\left(16^{\circ} \mathrm{C}, 10: 14 \mathrm{~L}: \mathrm{D}\right.$ and low conductivity) or of long hydroperiods (spring thermal fluctuating regime and intermediate conductivity). At $24^{\circ} \mathrm{C}$, age at reproduction of females from resting eggs almost doubled at low conductivity (in comparison with high conductivity). Low conductivity also reduced hatching time of resting eggs while it increased development time and age at maturity. In thermal fluctuating regime, degree-days to reproduction were about double than at constant $24^{\circ} \mathrm{C}$. Males, observed in all microcosms, reached maturity faster and had a shorter life span than females. Males initially outnumbered females, but later in the experiments females became dominant. We also evaluated the effect of conductivity and thermal regimes on other traits like recruitment from egg bank, voltinism and sex ratio. We discuss whether our observations on a small population from temporary pools could be considered part of a diversified bet-hedging strategy.
\end{abstract}

Key words: ephemeral pools, habitat predictability, recruitment from egg bank, thermal fluctuation, degree days.

Received: September 2012. Accepted: Janaury 2013.

\section{INTRODUCTION}

Temporary pools are a useful model system for studying how the evolution of appropriate life-history strategies allows populations to persist in highly variable environmental conditions (De Meester et al., 2005). Aquatic crustaceans inhabiting ephemeral ponds exhibit the same basic life history patterns: fast development (days to few weeks to maturity) and persistence through dry phases thanks to desiccation-resistant dormant stages (cysts or resting eggs) (Fryer, 1996; Hairston, 1998). This requires life-history adaptations that allow organisms to schedule the appropriate timing (the phenology) of dormant stage activation, development, mating and reproduction onset and production of dormant stages (Brendonck et al., 1998; Forrest and Miller-Rusching, 2010). Dormancy is interrupted by appropriate environmental cues (e.g. changes in photoperiod, temperature, conductivity) that are associated with water presence (Brendonck et al., 1998). Recruitment from dormant eggs over more than one filling event has been observed in several species as well as the accumulation of an egg bank. Resting eggs in the sediments have a key role in the persistence of populations when hydroperiod varies unpredictably and all adults may die without reproducing (Brendonck and De Meester, 2003; Ripley et al., 2004; Evans and Denney, 2005).

Temporary pond species often are made up of univoltine organisms with a life cycle that is much shorter than the mean life of the pool and of bivoltine organisms that live longer or by organisms that may alternate between univoltine and bivoltine life cycles (Wilbur and Rudolf, 2006). Bivoltine organisms may produce dormant and non-dormant eggs: the decision entails important risks/choices but might produce significant increases in fitness when hydroperiod is long (Roff, 1980; Stearns, 1992). Organisms must take advantage of pond filling when it occurs and hedge their bets for the possibility of favourable long lasting hydroperiod so that more than one life cycle may be completed and a larger amount of dormant stages produced. In ephemeral pools hydroperiod predictability varies accordingly to latitude and season (Brendonck et al., 1998; 
Hulsmans et al., 2008). Earlier onset of development and increased voltinism may promote faster population growth and have major implication for egg bank accumulation. Moreover, since voltinism can determine the number of generations produced by a population per filling event, it can have profound ecological and evolutionary implications for a species (Altermatt, 2010).

The timing of many phenological events (e.g. hatching of the resting eggs, onset of development and reproduction) results from a complex interplay among organism genotypes and relevant environmental variables such as temperature and light. Temperature, food availability and seasonal time constraints regulate life cycle duration of copepods that can alternate between univoltine or multivoltine strategies (Allan and Goulden, 1980; Chen and Folt, 1996; Twombly et al., 1998; Gerten and Adrian, 2002; Winder and Schindler, 2004; Adrian et al., 2009). Environmental conditions may alter life cycle strategies, which differ from year-round active stages to strong seasonality with resting stages of varying length (Hairston et al., 1996). In large Branchiopods, during an inundation cycle of shallow and short-lived pools, changes in temperature, osmotic pressure and oxygen concentration are the most important clues of the suitability of environmental conditions for the hatching of resting stages, and the growth and reproduction of newborns (Brendonck, 1996; Brendonck et al., 1998; Brendonck and De Meester, 2003). In short-lived aquatic invertebrates, warmer temperatures and longer growing seasons (hydroperiod) may allow additional generations per inundation.

Ostracods, an important component of temporary pool communities, survive adverse periods as resting eggs (Meisch, 2000). The population dynamics of only a few species from freshwater temporary pools has been described (Ganning, 1971; Aguilar-Alberola and MesquitaJoanes, 2011). According to McLay (1978), difference in hatching phenology and recruitment of resting eggs are among the factors that allow the coexistence of Cyprinotus (Heterocypris) carolinensis and Herpetocypris reptans in temporary pools. In Heterocypris incongruens, clones with a different genetic make up modulate their survival, production and hatching of resting eggs so that, by seasonal clonal succession, the species is present through the drastically different seasonal environmental conditions of northern Italy temporary ponds (Rossi et al., 1996, 2011). In different European clones of the vernal species Eucypris virens, resting egg production, variation in voltinism and hatching delay are the result of latitudinal adaptation in response to day-length duration, a reliable predictor of drought or adverse conditions (Otero et al., 1998).

Heterocypris barbara (Gauthier and Brem, 1928), first observed in Northern Africa, is widely distributed in the circum-Mediterranean area and has also been found in Hungary, Germany, Poland, and the Czech Republic (Bal- tanás et al., 1990; Meisch, 2000). The nominal form is reported to be restricted to temporary and permanent freshwater habitats while the variety inermis is known to occur in saline inland waters (Baltanás et al., 1990; Meisch, 2000). Males are commonly reported, but they are absent from some of the inermis populations (Meisch, 2000). In Central Europe, Sywula et al. (1991) described the succession of three generations from late spring to autumn in Polish permanent ponds.

On Lampedusa island (Isole Pelagie, Sicily channel, Italy), both amphimictic and parthenogenetic females of $H$. barbara were described and both forms coexist in at least one temporary freshwater pond (Rossi et al., 2003, 2004, 2007). The Mediterranean area has a predictable dry summer, but the rainfall pattern and hence the onset and duration of the wet winter season is highly variable from year to year. Due to erratic rainfall and high evaporation rates, the pools, may have from no to several hydroperiods during one wet season. As a consequence hydroperiods may be shorter than the organism life cycle. The presence and persistence of $H$. barbara in these pools has a finite, though variable, length of time in which organisms emerge from resting eggs, grow, reproduce and return to resting stage. We have described the role of temperature, oxygen concentration, $\mathrm{pH}$ and conductivity in hatching phenology of resting eggs (Rossi et al., 2004). Hypoxia and high conductivity delayed or prevented hatching and resting egg may remain dormant until the following inundation (Rossi et al., 2004, 2012).

Here, we investigate the life cycle of a sexual population of H. barbara from Lampedusa and report how environmental conditions, mimicking different seasonal periods, affect the species voltinism. Our purpose was an exploratory study of the complex and little known $H$. barbara life cycle. Given the nature of the studied phenomena we did not set up an appropriate experimental design to adequately test for differences and interactions among the factors involved. We used microcosms established from dry sediments from Aria Rossa temporary pond and maintained at different combinations of photoperiod, temperature and conductivity considered proxy of hydroperiod predictability. We study how $H$. barbara manages to maintain an egg bank in a Mediterranean region with unpredictable hydroperiods. The literature on the ecology and population biology of $H$. barbara is scarce and few studies have combined laboratory results with field observations.

\section{METHODS}

On Lampedusa island ephemeral, vernal pools only fill up after abundant and persistent rainfall that unpredictably occurs from October to March. During the rainy season, mean monthly precipitation is low $(20-58 \mathrm{~mm})$, minimum air temperature varies between $11^{\circ} \mathrm{C}$ and $19^{\circ} \mathrm{C}$ 
and maximum air temperature varies between 15 and $24^{\circ} \mathrm{C}$. Photoperiod varies between 10:14 L:D (December) and 12:12 L:D (late September and March). Hydroperiod depends on total precipitation, the pattern of rainfall and temperature, the pond size and depth. It affects the length of time available for reproduction, resource availability and the duration of population increase. If rainfall is sporadic, ponds can fill and dry rapidly several times during the rainy season. This can lead to population extinction due to the drying up of partially filled or small pools. On the other hand, hydroperiod may be longer than one life cycle allowing overlapping generations.

The ephemeral pond Aria Rossa, located in a flat rocky area of Lampedusa ( $\left.35^{\circ} 31^{\prime} 26^{\prime \prime} \mathrm{N} 12^{\circ} 34^{\prime} 15^{\prime \prime} \mathrm{E}\right)$, is small (1- to 30-m wide) and shallow (depth up to $20 \mathrm{~cm}$ ), appears during the rainy season and exists for an unpredictable time (Bellavere et al., 1999). It hosts an amphimictic population of $H$. barbara (Rossi et al., 2007). In order to evaluate how conductivity, temperature and photoperiod affect the termination of dormancy, the life cycle and the dynamics of natural amphimictic populations of H. barbara, laboratory microcosms were set up by hydrating sediments from Aria Rossa with $500 \mathrm{ml}$ distilled water in transparent cylindrical uncovered PET containers ( $8 \mathrm{~cm}$ diameter, $18 \mathrm{~cm}$ height) (Rossi et al., 2004). In microcosms free mating may occur at the appropriate instar. Different conductivities were obtained by setting up microcosms using variable amounts of sediment: $40 \mathrm{~g}$, for low conductivity (LC), 60-70 g for intermediate conductivity (IC) or 160-200 g for high conductivity (HC). The experiment was carried out in different controlled conditions. Microcosms were maintained in thermal chambers at $24^{\circ} \mathrm{C}$ and 12:12 L:D photoperiod or at $16^{\circ} \mathrm{C}$ and $10: 14$ L:D photoperiod. The experiment was not factorial. Three different conductivities (low, intermediate and high) were used at $24^{\circ} \mathrm{C}$ and 12:12 L:D photoperiod. These environmental conditions mimicked an autumnal or spring inundation when both rain and hence hydroperiod are highly unpredictable and conductivity may be highly variable (Rossi et al., in preparation). Only one, low, conductivity was used at $16^{\circ} \mathrm{C}$ and 10:14 L:D photoperiod as these conditions simulated a winter inundation when rainfall and hydroperiod are relatively predictable and abundant. The experiment lasted 7 months, from November to May.

To mimic the natural thermal fluctuations that affect invertebrate development (Hubbs, 1964; Sweeney and Schnack, 1977; Scholnick, 1995), two more microcosms were maintained on the laboratory windowsill from February to May. Throughout the experimental period, in our laboratory $\left(45^{\circ}\right.$ latitude $\left.\mathrm{N}\right)$, temperature and photoperiod were similar to the early spring breeding hydroperiod in Lampedusa. Natural day-length varied approximately between 10 and 15 hours and water temperature was monitored and recorded every hour over the entire experimental period using a data logger (Escort Junior) to compute degree-day units (DD), the daily accumulation of heat above a minimum threshold temperature over time (Obedzinski and Letcher, 2004). This physiological time, which provides a common reference for the development of ectotherms, accounted for the influence of temperature on the dynamics of $H$. barbara population in non-stable thermal regimes and allowed the comparison of stable and fluctuating thermal regime experiments. DD units were calculated assuming a development threshold of $12^{\circ} \mathrm{C}$ using Degree Day Utility v. 2.0 and the single sine method (UC IPM, 1990). In Fig. 1 the relationship between days from the beginning of the experiment (hydroperiod) and DD in all three experimental condition was reported for comparison. In thermal fluctuating regime (FT), two conductivities (HC and IC) were used to mimic spring inundation when rains are highly unpredictable and conductivity tends to increase due to increasing evaporation.

In all microcosms, water was maintained at constant level. Conductivity (Knick Portamess Conductimeter 910), pH (Knick Portamess pH meter 912) and oxygen concentration (Oxygen meter Aqua Lytic OX22), were measured every seven days. Once a week, the water of each microcosm was siphoned and organisms were handsorted under a stereo microscope. The number of juveniles, adult males, adult females and ovigerous females were recorded. By previous laboratory observations we knew that at $24^{\circ} \mathrm{C}$ and 12:12 L:D, H. barbara eggs hatch within 13 days and $156 \mathrm{DD}$ after the microcosm filling (Rossi et al., 2003, 2004). Moreover, males and ovigerous females were distinguishable by the observation trough the transparent carapace of long sperm ducts or of eggs in the ovary. Each individual was measured and then returned to its original microcosm. In each microcosm the number of generations was estimated by considering the size frequency distribution of measured organisms and the time of appearance of the first few ovigerous females over the duration of the experiment (Fig. 2).

ANOVA was used to test for differences in size of adult males and ovigerous females. The Scheffé test was used for pairwise comparison. To avoid problems associated with repeated measures, the effect of generation on adult size was also estimated by the correlation of size and DD. As most of our results are qualitative no further statistics were applied.

\section{RESULTS}

Three different conductivity levels were recorded in microcosms set up using different quantity of sediment from Aria Rossa: high conductivity (HC) $2.0-2.7 \mathrm{mS} \mathrm{cm}^{-1}$, intermediate conductivity (IC) $1.0-1.1 \mathrm{mS} \mathrm{cm}^{-1}$ and low conductivity (LC) $0.5-0.6 \mathrm{mS} \mathrm{cm}$ cm $^{-1}$ (LC) (Tab. 1). In all microcosms mean oxygen concentration varied from 2.7 to $4.3 \mathrm{mg} \mathrm{L}^{-1}$ and mean $\mathrm{pH}$ value varied between 8.1 and 8.6 
(Tab. 1). In thermal fluctuation conditions, DD accumulation trend, from sediment hydration to the end of the experiment, was more similar to the recorded trend at constant $24^{\circ} \mathrm{C}$ than at constant $16^{\circ} \mathrm{C}$ (Fig. 1).

In all microcosms hatchlings were observed and more than one putative generation (cohort) was recorded during the experimental period. In all microcosms and in all putative generations, with the exclusion of generations II and III at $24^{\circ} \mathrm{C}$ and IC, the first adult males appeared earlier than the first adult females. At $24^{\circ} \mathrm{C}$ and 12:12 L:D, DD at recording of ovigerous females from resting eggs (generation I) decreased with increasing conductivity, from $156 \mathrm{DD}$ (13 days from hydration) at $\mathrm{HC}$ to $276 \mathrm{DD}$ at LC (Tab. 2). Estimated number of generations was up to 5: at IC, in the putative generation III and IV, no males were detected (Tab. 2). In generation I, mean body size of adult males and ovigerous female decreased significantly with decreasing conductivity (males:
$\mathrm{F}_{2,47}=60.4, \mathrm{P}<0.001$; females, $\left.\mathrm{F}_{2,129}=117.4, \mathrm{P}<0.001\right)$. At $\mathrm{LC}$, the interval between ovigerous females of putative successive generations were very similar (between 42 and 50 days) while, at $\mathrm{HC}$ and IC the number of days between putative successive generations was very variable (from 15 to 79 days) with the highest value between generations III and IV (79 days). In general, mean body size of adult males and ovigerous females decreased with generation (Tab. 2) and the relationship was affected by conductivity. Mean body size was significantly related to generation, at $\mathrm{HC}\left(\mathrm{r}^{2}=0.65\right.$, $\mathrm{F}_{1,314}=569.6, \mathrm{P}<0.001$ in females; $\mathrm{r}^{2}=0.72, \mathrm{~F}_{1,85}=216.8$, $\mathrm{P}<0.001$ in males), but was poorly predicted by generation both at $\mathrm{IC}\left(\mathrm{r}^{2}=0.46, \mathrm{~F}_{1,221}=190.8, \mathrm{P}<0.001\right.$ in females; $\mathrm{r}^{2}=0.66, \mathrm{~F}_{1,10}=19.3, \mathrm{P}<0.01$ in males $)$ and at $\mathrm{LC}\left(\mathrm{r}^{2}=0.17\right.$, $\mathrm{F}_{1,83}=17.0, \mathrm{P}<0.001$ in females; $\mathrm{r}^{2}=0.02, \mathrm{~F}_{1,51}=1.1, \mathrm{P}=0.291$ in males) (Fig. 2). The number of males and ovigerous females decreased with generation and sex ratio tend to be female biased (with the exception of generation I at LC).

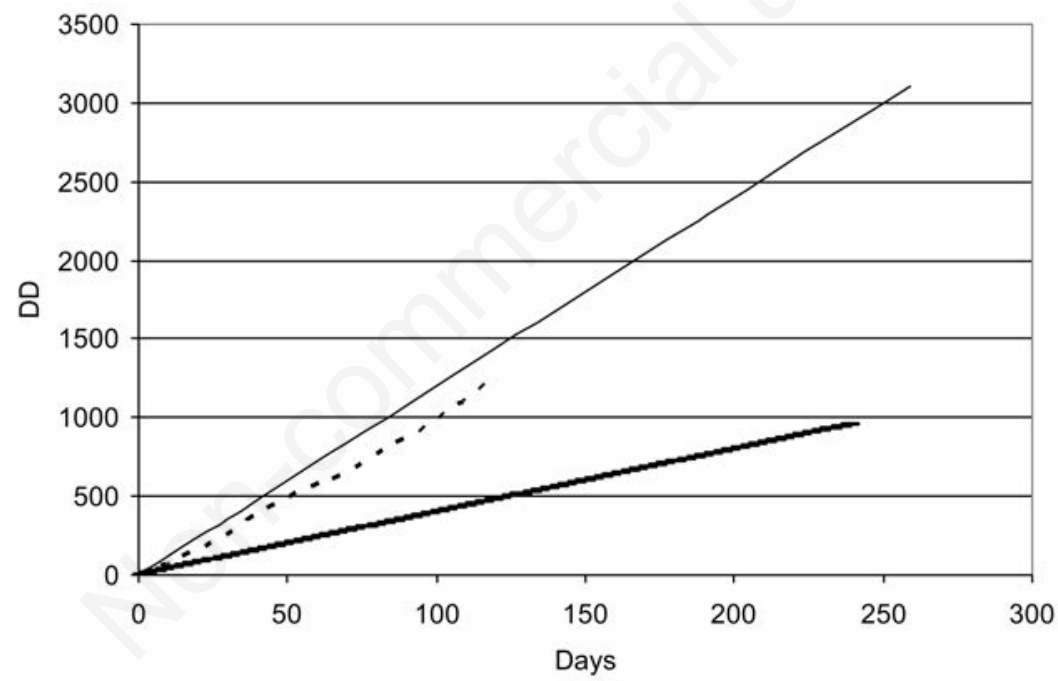

Fig. 1. Relationship between days and degree days (DD) accumulation over the experimental period at $24^{\circ} \mathrm{C}$ (thin line), at $16^{\circ} \mathrm{C}($ thick line) and at thermal fluctuating regime (hatched line).

Tab. 1. Thermal regime, mean values (with standard deviation in parenthesis) of conductivity, $\mathrm{pH}$ and oxygen concentration over the experimental period for each microcosm.

\begin{tabular}{|c|c|c|c|c|c|c|c|c|}
\hline Microcosm & $\mathrm{T}\left({ }^{\circ} \mathrm{C}\right)$ & Conductivity $\left(\mathrm{mS} \mathrm{cm}^{-1}\right)$ & $\mathrm{pH}$ & Oxygen concentration $\left(\mathrm{mg} \mathrm{L}^{-1}\right)$ & Gen & $\mathrm{N}$ & $\mathrm{M}$ & $\mathrm{F}$ \\
\hline AR1 (HC) & 24 & $2.0(0.35)$ & $8.5(0.29)$ & $2.7(0.62)$ & 5 & 432 & 86 & 233 \\
\hline AR2 (IC) & 24 & $1.1(0.07)$ & $8.4(0.29)$ & $2.7(0.58)$ & 5 & 300 & 12 & 160 \\
\hline ARII (LC) & 24 & $0.6(0.06)$ & $8.4(0.29)$ & $2.9(0.53)$ & 5 & 225 & 53 & 71 \\
\hline AR II 10 (LC) & 16 & $0.5(0.07)$ & $8.1(0.22)$ & $2.8(0.77)$ & 3 & 330 & 53 & 187 \\
\hline M1 (HC) & FT & $2.7(0.55)$ & $8.5(0.24)$ & $4.1(0.87)$ & 3 & 313 & 62 & 133 \\
\hline M2 (IC) & FT & $1.0(0.15)$ & $8.6(0.25)$ & $4.3(0.82)$ & 3 & 238 & 30 & 163 \\
\hline
\end{tabular}

T, constant temperature; HC, high conductivity; IC, intermediate conductivity; LC, low conductivity; Gen, minimum number of estimated generations; $N$, total number of measured individuals; $M$, number of measured males; $F$, number of measured ovigerous females; $F T$, fluctuating temperature. 
At $16^{\circ} \mathrm{C}, 10: 14 \mathrm{~L}: \mathrm{D}$ and $\mathrm{LC}$, ovigerous females of generation I were recorded at $284 \mathrm{DD}$ that is within 71 days from hydration (Tab. 2; Fig. 3). By using DD as measure unit, we can observe that this physiological time is very similar to $276 \mathrm{DD}$ at recording of generation I ovigerous females at $\mathrm{LC}$ at $24^{\circ} \mathrm{C}$. As expected, at $16^{\circ} \mathrm{C}$ it needs more time than at $24^{\circ} \mathrm{C}$ to accumulate a similar amount of DD. Estimated number of generations was 3 and the mean size of adult males and ovigerous females decreased with generation (Tab. 2). The number of days between generations I and II (33 days) was almost half than between generation II and III (76 days). The number of males and ovigerous females decreased with generation and sex ratio was female biased.

Under a thermal fluctuating regime (FT), ovigerous females of generation I were recorded at 299 DD (within 33 days from hydration) at both HC and IC (Tab. 2; Fig. 4). Mean body size of adult males and ovigerous female of generation I was smaller at $\mathrm{HC}$ than at IC (males: $\mathrm{F}_{1,60}=29.0$, $\mathrm{P}<0.001$; females: $\mathrm{F}_{1,109}=412.6, \mathrm{P}<0.001$ ). Estimated number of generations was 3 and the number of days (43) between generations was independent to generations and conductivity (Tab. 2). Mean body size of ovigerous females decreased from generation I to generation III at $\mathrm{HC}$ while mean body size of ovigerous females increased from generation I to generation III at IC (Tab. 2; Fig. 4). The number of males and ovigerous females decreased from generation I to generation III and sex ratio was female biased.

At LC, mean size of ovigerous females of generation I was smaller at $16^{\circ} \mathrm{C}$ than at $24^{\circ} \mathrm{C}\left(\mathrm{F}_{1,22}=11.830\right.$, $\mathrm{P}=0.002$ ). At both IC and HC mean body size of adult males and ovigerous females of generation I was larger at $24^{\circ} \mathrm{C}$ than at $\mathrm{FT}$ (IC, males: $\mathrm{F}_{1,20}=22.7, \mathrm{P}<0.001$; females $\mathrm{F}_{1,102}=241.0, \mathrm{P}<0.001$; HC males: $\mathrm{F}_{1,78}=102.1, \mathrm{P}<0.001$; females $\mathrm{F}_{1,130}=120.4, \mathrm{P}<0.001$ ).

\section{DISCUSSION}

Hatching phenology of $H$. barbara resting eggs from Lampedusa and recruitment periods varied according to thermal regime and conductivity and more than one generation per inundation was observed in all microcosms. As observed by Ganning (1971), salinity and temperature have a strong influence on development and voltinism. The main problem is to distinguish between true generations, since individuals from the same parents might ap-

Tab. 2. Days and degree days from sediment hydration to the estimated appearance of putative generation for each microcosm and putative generation.

\begin{tabular}{|c|c|c|c|c|c|c|c|}
\hline Microcosm & Gen & Days & $\mathrm{DD}$ & NM & $\mathrm{mm} \mathrm{M}$ & $\mathrm{NF}$ & $\mathrm{mm} \mathrm{F}$ \\
\hline AR1 (HC) & $\begin{array}{l}\text { I } \\
\text { II } \\
\text { III } \\
\text { IV } \\
\text { V }\end{array}$ & $\begin{array}{c}13 \\
28 \\
48 \\
127 \\
177\end{array}$ & $\begin{array}{c}156 \\
336 \\
1080 \\
1524 \\
2124\end{array}$ & $\begin{array}{c}35 \\
11 \\
29 \\
9 \\
3\end{array}$ & $\begin{array}{l}1.28(0.071)^{\mathrm{a}} \\
1.21(0.037)^{\mathrm{a}} \\
1.06(0.037)^{\mathrm{b}} \\
1.06(0.032)^{\mathrm{b}} \\
0.95(0.070)^{\mathrm{c}}\end{array}$ & $\begin{array}{c}78 \\
66 \\
67 \\
18 \\
4\end{array}$ & $\begin{array}{l}1.64(0.082)^{\mathrm{a}} \\
1.55(0.082)^{\mathrm{a}} \\
1.29(0.077)^{\mathrm{b}} \\
1.31(0.049)^{\mathrm{b}} \\
1.29(0.059)^{\mathrm{b}}\end{array}$ \\
\hline AR2 (IC) & $\begin{array}{l}\text { I } \\
\text { II } \\
\text { III } \\
\text { IV } \\
\text { V }\end{array}$ & $\begin{array}{c}15 \\
28 \\
48 \\
127 \\
177\end{array}$ & $\begin{array}{c}180 \\
336 \\
576 \\
1524 \\
2124\end{array}$ & $\begin{array}{l}5 \\
1 \\
- \\
- \\
6\end{array}$ & $\begin{array}{c}1.25(0.110)^{\mathrm{a}} \\
1.14(-) \\
- \\
- \\
1.09(0.110)^{\mathrm{b}}\end{array}$ & $\begin{array}{c}47 \\
78 \\
16 \\
1 \\
18\end{array}$ & $\begin{array}{c}1.47(0.033)^{\mathrm{a}} \\
1.46(0.053)^{\mathrm{a}} \\
1.31(0.115)^{\mathrm{b}} \\
1.33(-) \\
1.30(0.096)^{\mathrm{b}}\end{array}$ \\
\hline ARII (LC) & $\begin{array}{l}\text { I } \\
\text { II } \\
\text { III } \\
\text { IV } \\
\text { V }\end{array}$ & $\begin{array}{c}23 \\
69 \\
119 \\
161 \\
188\end{array}$ & \begin{tabular}{c|}
276 \\
828 \\
1428 \\
1932 \\
2256
\end{tabular} & $\begin{array}{c}10 \\
8 \\
12 \\
6 \\
17\end{array}$ & $\begin{array}{c}1.00(0.070)^{\mathrm{a}} \\
1.13(0.071)^{\mathrm{bc}} \\
1.15(0.063)^{\mathrm{c}} \\
1.08(0.049)^{\mathrm{abc}} \\
1.06(0.050)^{\mathrm{ab}}\end{array}$ & $\begin{array}{c}7 \\
10 \\
9 \\
16 \\
29\end{array}$ & $\begin{array}{c}1.44(0.016)^{\mathrm{a}} \\
1.36(0.076)^{\mathrm{ab}} \\
1.45(0.117)^{\mathrm{a}} \\
1.37(.093)^{\mathrm{ab}} \\
1.32(0.056)^{\mathrm{b}}\end{array}$ \\
\hline ARII 10 (LC) & $\begin{array}{l}\text { I } \\
\text { II } \\
\text { III }\end{array}$ & $\begin{array}{c}71 \\
121 \\
237\end{array}$ & $\begin{array}{l}284 \\
484 \\
948\end{array}$ & $\begin{array}{c}3 \\
45 \\
5\end{array}$ & $\begin{array}{l}0.87(0.090)^{\mathrm{a}} \\
1.30(0.072)^{\mathrm{b}} \\
1.14(0.128)^{\mathrm{c}}\end{array}$ & $\begin{array}{c}17 \\
156 \\
14\end{array}$ & $\begin{array}{l}1.34(0.074)^{\mathrm{a}} \\
1.74(0.092)^{\mathrm{b}} \\
1.46(0.087)^{\mathrm{c}}\end{array}$ \\
\hline M1 (HC) & $\begin{array}{c}\text { I } \\
\text { II } \\
\text { III }\end{array}$ & $\begin{array}{c}33 \\
76 \\
119\end{array}$ & $\begin{array}{c}299 \\
726 \\
1234\end{array}$ & $\begin{array}{c}45 \\
11 \\
6\end{array}$ & $\begin{array}{l}1.06(0.110)^{\mathrm{a}} \\
1.00(0.066)^{\mathrm{b}} \\
1.11(0.050)^{\mathrm{a}}\end{array}$ & $\begin{array}{l}54 \\
64 \\
15\end{array}$ & $\begin{array}{l}1.51(0.040)^{\mathrm{a}} \\
1.28(0.050)^{\mathrm{b}} \\
1.29(0.055)^{\mathrm{b}}\end{array}$ \\
\hline M2 (IC) & $\begin{array}{l}\text { I } \\
\text { II } \\
\text { III }\end{array}$ & $\begin{array}{c}33 \\
76 \\
119\end{array}$ & $\begin{array}{c}299 \\
726 \\
1234\end{array}$ & $\begin{array}{l}17 \\
8 \\
5\end{array}$ & $\begin{array}{l}0.87(0.176)^{\mathrm{a}} \\
1.07(0.135)^{\mathrm{b}} \\
1.19(0.046)^{\mathrm{b}}\end{array}$ & $\begin{array}{l}57 \\
89 \\
17\end{array}$ & $\begin{array}{l}1.34(0.047)^{\mathrm{a}} \\
1.32(0.077)^{\mathrm{a}} \\
1.38(0.046)^{\mathrm{b}}\end{array}$ \\
\hline
\end{tabular}

Gen, putative generation; DD, degree days; $N M$, number of males; mm $M$, mean size in mm (with standard deviation in parenthesis) of males; NF, number of ovigerous females; $\mathrm{mm} F$, mean size in $\mathrm{mm}$ (with standard deviation in parenthesis) of ovigerous females; HC, high conductivity; IC, intermediate conductivity; LC, low conductivity. ${ }^{a, b, c}$ Within microcosm and within gender, generations marked with the same letter are not significantly different in mean size. 

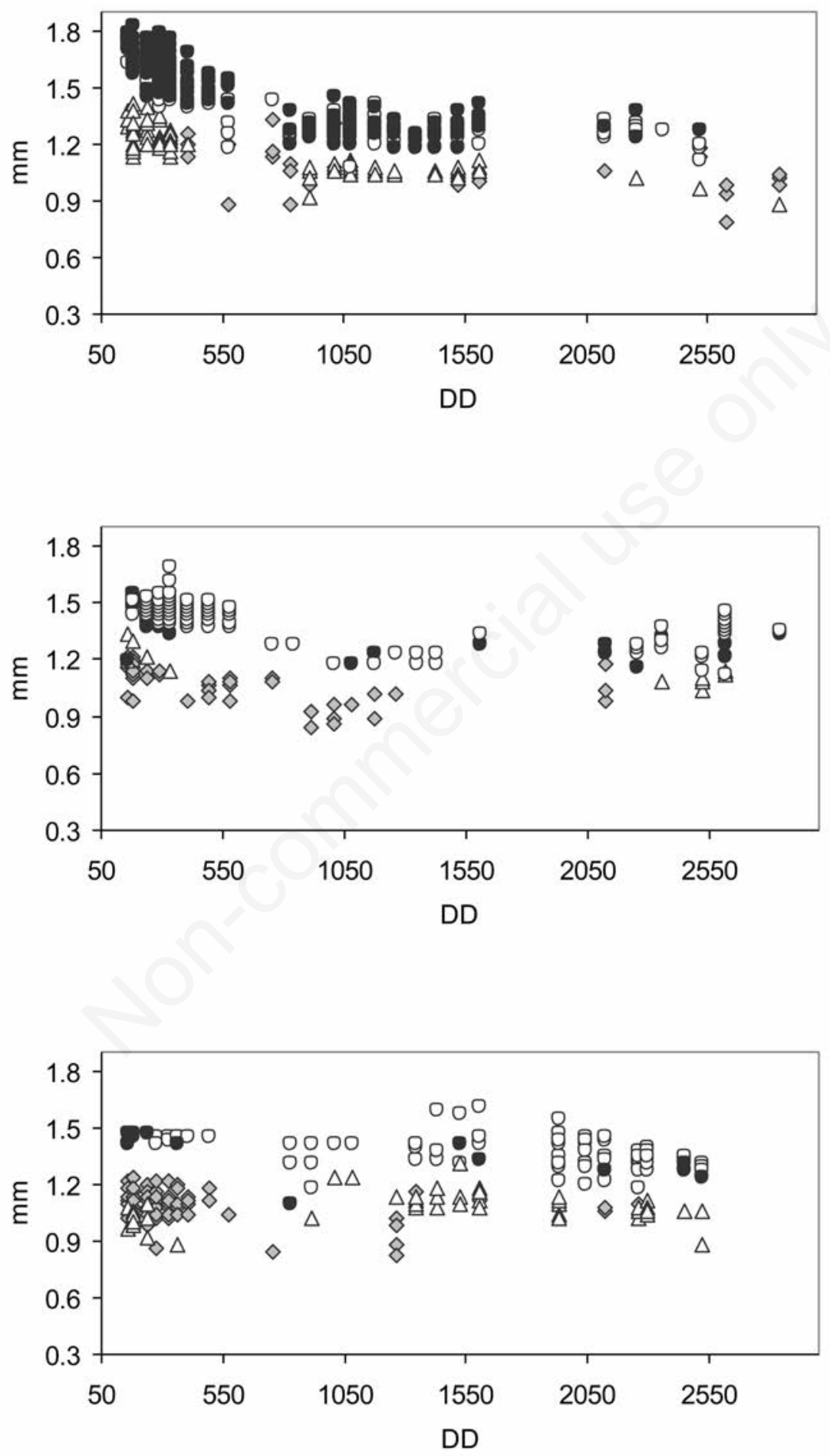

Fig. 2. Body size over the experimental period in organisms reared at $24^{\circ} \mathrm{C} 12: 12 \mathrm{~L}: \mathrm{D}$ photoperiod and three different conductivities: $\mathrm{HC}$ (top), IC (middle) and LC (down). Open circles refer to adult females, closed circles refer to ovigerous females, open triangles refer to males, diamonds refer to juveniles. Degree days (DD) were computed from the beginning of the experiment. 
pear at very different times due to a delayed hatching (Havel and Talbott, 1995).

In most microcosms the succession of different generations was linked to a decrease in mean body size of both males and ovigerous females. This is in accordance with our preliminary observations that mean size of organisms from resting eggs should be larger than from non resting eggs, especially at high conductivity (Martorella, unpublished data). A similar phenomenon was described in Daphnia where it was related to stored energy reserve being larger in resting than in non-resting eggs (Arbaciauskas and Lampert, 2003), although the structural difference between the two kind of eggs in Cladocera suggest caution in comparing observations from the two taxa. Differences in body size among generations, as well as between genders, may be linked to variation in competitive ability and may reduce intraspecific competition (Hutchinson, 1967; van Harten, 1983; Baltanás et al., 2000). However, at $16^{\circ} \mathrm{C}$ (LC) and FT (IC), the mean size of ovigerous females increased in the putative generations II and III. As adults do not moult, we may exclude that ovigerous females increase their size by aging (Cohen and Morin, 1990). This should confirm that at least a second delayed recruitment period from egg bank occurred in laboratory conditions that simulate abundant inundation and a predictable long hydroperiod $\left(16^{\circ} \mathrm{C}, 10: 14 \mathrm{~L}: \mathrm{D}\right.$ and LC) or persistence of favourable hydroperiod (FT and IC). Hatching of resting eggs following rains results from a trade-off between hatching success and the likelihood of completing life cycle. Limiting hatching to the initial phase of inundation may be a mechanism to prevent the risk of egg bank impoverishment. This occurs when hydroperiod is shorter than the mean generation time and hatching of resting eggs is followed by reproductive failure, due, for instance, to low temperature or to desiccation of the habitat. Ignoring any potential costs of remaining dormant, if habitat quality could be predicted, the best strategy would be to hatch only when hydroperiod is favourable for recruitment. We know that a proportion of resting eggs of $H$. barbara from egg bank does not hatch after a first inundation event and displays a log-term dormancy (Rossi et al., 2004). The production of both resting and non resting eggs as well as delayed recruitment from them, might be seen as part of a diversified bet-hedging strategy to spread the risk of extinction and to bet on advantage of any extra time available for reproduction (Hairston et al, 1995, 1996; Simovich and Hathaway, 1997; Rossi et al., 2012). Martins et al. (2008) referred to a bet-hedging strategy in describing asynchronous hatching of resting eggs in sexual populations of Eucypris virens and in clonal populations of $H$. incongruens and $E$. virens hatching phenology is modulated by the interaction between genotype, environment and maternal effects (Rossi and Menozzi, 1990, 1993, 2012a). The role of the genetic component in hatching modulation of dormant eggs has been observed or hypothesised in Cladocera (De Meester and De Jager, 1993; Pfender and Deng, 1998; Alekseev and Lampert, 2001). Differences in allele frequencies at PGM and GPI loci were observed in $\mathrm{H}$. barbara from Aria Rossa microcosms inundated at different temperature and photoperiod conditions (Rossi et al., 2004). We cannot rule out that differential responses to trigger stimuli were linked to genetically dependent hatching rates while, a delayed recruitment from resting eggs, allows a generation overlapping reducing the risk of inbreeding depression in small sexual populations (Ellner and Hairston, 1994; Rossi and Menozzi, 2012b). Moreover, having more generations in a given hydroperiod could allow more rapid adaptation, provided selection pressures experienced by the different generations that are sufficiently similar (Rossi et al., 2003; Forrest and MillerRushing, 2010).

Low conductivity, which is in the field generally associated with rainfall, triggers the end of dormancy in freshwater Branchiopods and seems more relevant in maximising the chances for successful recruitment, especially in arid regions (Brendonck, 1996; Brendonck et al., 1998; Beladjal et al., 2003). In Ostracods, it is known that conductivity modulates hatching phenology, survival and larval moult but its role is contrasting (De Deckker, 1983; Mezquita et al., 1999). In fact the appearance of adult stages was delayed and mean size of adult stage decreased with conductivity decreasing. As the calcification of the valves represents a critical stage in ostracod post-moult development, too low conductivity has a negative effect on ostracod survival and growth (Mezquita et al., 1999). In the field, evaporation, increasing with temperature, leads to increase in conductivity that either inhibits recruitment from egg bank or has a positive effect on ostracod survival, growth and ultimate size: developmental time is faster at higher temperatures and at optimal conductivity (Cohen and Morin, 1990). We observed that a decrease in conductivity delayed time at maturity of females with respect to microcosm inundation. At $24^{\circ} \mathrm{C}$, days and $\mathrm{DD}$ at recording of first generation ovigerous females were inversely related to conductivity and they almost doubled from $\mathrm{HC}$ to LC. The ephemeral nature of the pool exposes organisms to two important selective constraints: successful hatching of resting eggs at an appropriate time, life cycle completion and egg bank enrichment with production of further resting eggs. Conductivity affects differently two main phases of H. barbara life cycle: low conductivity accelerates hatching time of resting eggs while increases development time and age at maturity. This seems an obvious adaptation to the unpredictable hydroperiod in temporary pools. In the field, conductivity should be the lower after the most abundant rains: this leads to rapid hatching of resting eggs. Then, if the conductivity increases depending on evaporation, it 


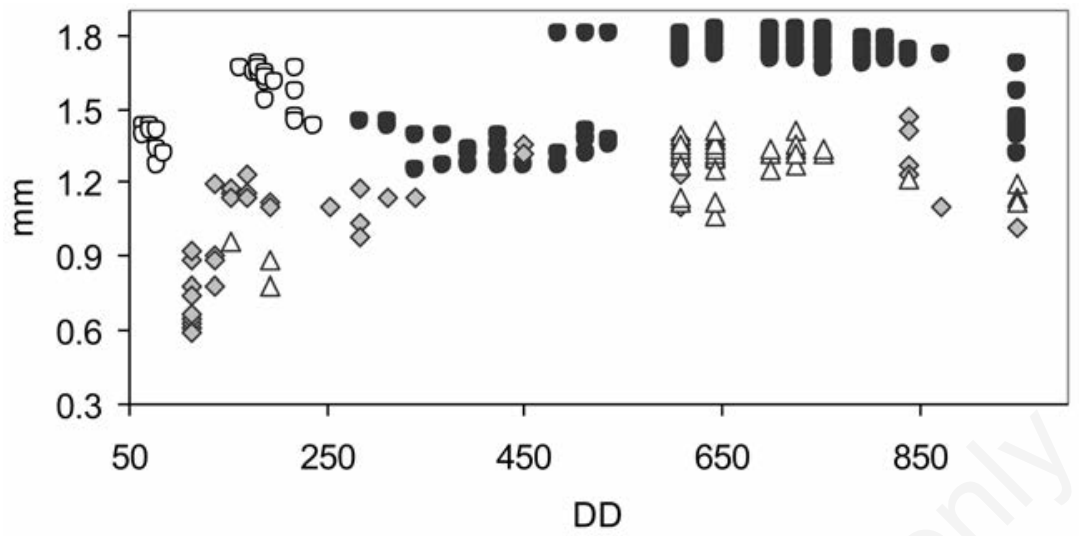

Fig. 3. Body size over the experimental period in organisms reared at $16^{\circ} \mathrm{C} 10: 14 \mathrm{~L}$ :D photoperiod and low conductivity. Open circles refer to adult females, closed circles refer to ovigerous females, open triangles refer to males, diamonds refer to juveniles. Degree days (DD) were computed from the beginning of the experiment.
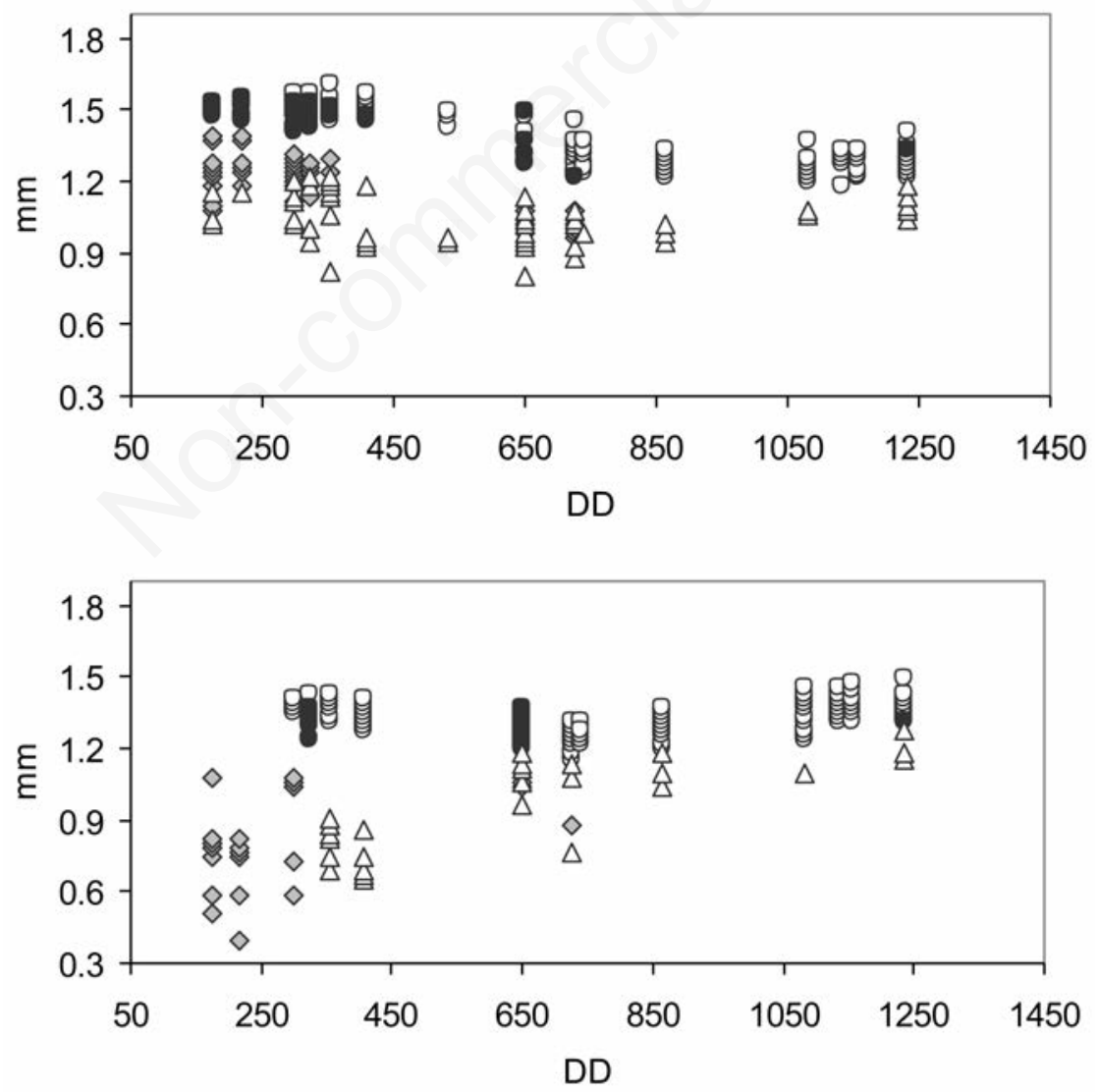

Fig. 4. Body size over the experimental period in organisms reared at thermal fluctuating regime (FT), increasing photoperiod and two different conductivities: HC (top) and IC (down). Open circles refer to adult females, closed circles refer to ovigerous females, open triangles refer to males, diamonds refer to juveniles. Degree days (DD) were computed from the beginning of the experiment. 
would be advantageous that a higher conductivity accelerates the development time of juveniles and inhibits delayed recruitment from resting eggs that should risk to hatch too late for completing their life cycle. At the same time, resting eggs may remain viable in the egg bank and hatch the following hydroperiod (Rossi et al., 2004, 2012).

In FT, DD at reproduction of $H$. barbara females were about double than at $24^{\circ} \mathrm{C}$. Moreover, even if $\mathrm{LC}$ was not tested at FT, conductivity did not affect either hatching time of resting eggs or physiological time at completion of life cycle in generation I. This result confirms that natural thermal fluctuation, from day to night and from colder to wormer months, influence developing of invertebrates (Sweeney and Schnack, 1977; Ikeda, 1992; Montagnes and Weisse, 2000; Putnam et al. 2010), but an acceleration of growth rate in fluctuating temperatures was observed in Daphnia (Orcutt and Porter, 1983) and rotifers (Halbach, 1973). Moderate thermal fluctuations may be associated with faster growth while retardation of development was described in fluctuating regimes encompassing extreme temperatures (Worner, 1992; Thorp and Wineriter, 1981). The negative impact of temperature changes may be explained by stress effects and our results suggest that the effect of fluctuating temperatures cannot be completely predicted from data obtained in laboratory constant temperatures (Sweeney and Schnack, 1977; Worner, 1992).

In all microcosms, $H$. barbara males were recorded and adult males may initially outnumber females, but then the dominance switches. Males have shorter life span, and die shortly after copulation has taken place while females need to mature the fecundated eggs and lay them after copulation. This fact may account for sex biased ratio observed in several populations of non marine ostracodes that reproduce sexually (Chaplin et al., 1994). On the other hand, a female biased sex ratio could be a compensation for the higher death rate among females than that of males during the generative period. Males and females within a population may differ in optimal timing of emergence or reproduction, because precedence is often favoured in mate competition between males but is less strongly selected in females (Forrest and Miller-Rushing, 2010).

Our results seem in agreement with our previous observation that the sex ratio of hatchlings from resting eggs from laboratory hydrated sediments was never female biased while female dominance was observed in the natural source population (Bellavere et al., 2002; Rossi et al., 2004). A similar phenomenon was described in sexual lineages of $E$. virens and $H$. incongruens (Vandekerkhove et al., 2007; Rossi and Menozzi, 2012b). We suggest that female biased sex ratio, by reducing mating opportunity may affect egg to adult survival and that a difference in sex ratio between hatchlings from resting and non resting eggs may affect $H$. barbara voltinism and hence its pop- ulation growth. Moreover, as in H. incongruens, oogenesis was also found in some sexual virgin females (Rossi and Menozzi, 2012a), our record of ovigerous females might not represent certain fecundity and recruitment for successive generations.

Available evidence indicates that at least one population of H. barbara on Lampedusa island (namely Vallone della Forbice) includes both sexual and parthenogenetic females and that their relative abundance varies during the rain season (Bellavere et al., 2002; Rossi et al., 2007). Our results will be useful for a baseline evaluation of the role of hatching phenology and population dynamics in determining the coexistence of $H$. barbara apomictic and amphimictic lineages that we described in Vallone della Forbice (Rossi et al., 2007).

\section{ACKNOWLEDGMENTS}

The authors thank Dora Scudieri for her help with laboratory experiments and two anonymous reviewers for useful comments on the manuscript. This study was supported by the Italian Ministero dell'Università e della Ricerca Scientifica e Tecnologica PRIN 2007.

\section{REFERENCES}

Adrian R, O’Reilly CM, Zagarese H, Baines SB, Hessen DO, Keller W, Livingstone DM, Sommaruga R, Straile D, Van Donk E, Weyhenmeyer GA, Winderl M, 2009. Lakes as sentinels of climate change. Limnol. Oceanogr. 54:2283-2297.

Aguilar-Alberola JA, Mesquita-Joanes F, 2011. Population dynamics and tolerance to desiccation in a crustacean ostracod adapted to life in small ephemeral water bodies. Limnologica 41:348-355.

Alekseev V, Lampert W, 2001. Maternal control of resting-egg production in Daphnia. Nature 414:899-901.

Allan JD, Goulden CE, 1980. Some aspects of reproductive variation among freshwater zooplankton, p. 388-410. In: W.C. Kerfoot (ed.), Evolution and ecology of zooplankton communities. University Press of New England.

Altermatt F, 2010. Climatic warming increases voltinism in European butterflies and moths. Proc. R. Soc. B 277:12811287.

Arbaciauskas K, Lampert W, 2003. Seasonal adaptation of exephippio and parthenogenetic offspring of Daphnia magna: differences in life-history and physiology. Funct. Ecol. 17:431-437.

Baltanás A, Montes C, Martino P, 1990. Distribution patterns of ostracods in inberian saline lakes. influence of ecological factors. Hydrobiologia 197:207-220.

Baltanás A, Otero M, Arqueros L, Rossetti G, Rossi V, 2000. Ontogenetic changes in the carapace shape of the non-marine ostracod Eucypris virens (Jurine). Hydrobiologia 419:65-72.

Beladjal L, Peiren N, Vandekerckhove TTM, Mertens J, 2003. Different life histories of the co-occurring fairy shrimps Branchipus schaefferi and Streptocephalus torvicornis (Anostraca). J. Crust. Biol. 23:300-307.

Bellavere C, Benassi G, Calzolari M, Meisch C, McKenzie KG, 
Rossi V, 2002. Heterocypris (Crustacea: Ostracoda) from the Isole Pelagie (Sicily, Italy): the coexistence of different morphotypes. Ital. J. Zool. 69:53-57.

Bellavere C, Benassi G, McKenzie KG, Rossi V, 1999. Non-marine ostracoda (Crustacea) from temporary ponds in the Isole Pelagie (Sicily, Italy). Geosound 35:29-38.

Brendonck L, 1996. Diapause, quiescence, hatching requirements: what can we learn from fresh-water branchiopods (Crustacea: Branchiopoda: Anostraca, Notostraca, Conchostraca). Hydrobiologia 320:85-97.

Brendonck L, De Meester L, 2003. Egg banks in freshwater zooplankton: evolutionary and ecological archives in the sediment. Hydrobiologia 491:65-84.

Brendonck L, Riddoch BJ, Van de Weghe V, Van Dooren T, 1998. The maintenance of egg banks in very short-lived pools - a case study with anostracans (Branchiopoda). Arch. Hydrobiol. Spec. Issues Advanc. Limnol. 52:141-161.

Chaplin JA, Havel JE, Hebert PDN, 1994. Sex and ostracods. Trends Ecol. Evol. 9:435-439.

Chen CY, Folt CL, 1996. Consequences of fall warming for zooplankton overwintering success. Limnol. Oceanogr. 41:1077-1086.

Cohen AC, Morin JG, 1990. Patterns of reproduction in ostracodes: a review. J. Crust. Biol. 10:184-211.

De Deckker P, 1983. Notes on the ecology and distribution of nonmarine ostracods in Australia. Hydrobiologia 106:223-234.

De Meester L, De Jager H, 1993. Hatching of Daphnia sexual eggs. I. Intraspecific differences in the hatching responses of D. magna eggs. Freshwater Biol. 30:219-226.

De Meester L, Declerck S, Stocks R, Louette G, Van de Meutter, De Bie T, Michels E, Brendonck L, 2005. Ponds and pools as model systems in conservation biology, ecology and evolutionary biology. Aquatic Conserv. Mar. Freshw. Ecosyst. 15:715-725.

Ellner SP, Hairston NG Jr, 1994. Role of overlapping generations in maintaining genetic variation in a fluctuating environment. Am. Nat. 143:403-417.

Evans MEK, Dennehy JJ, 2005. Germ banking: bet-hedging and variable release from egg and seed dormancy. Q. Rev. Biol. 80:431-451

Forrest J, Miller-Rusching AJ, 2010. Toward a synthetic understanding of the role of phenology in ecology and evolution. Phil. Trans. R. Soc. B 365:3101-3112.

Fryer G, 1996. Diapause, a potential force in the evolution of freshwater crustaceans. Hydrobiologia 320:1-14.

Ganning B, 1971. On the ecology of Heterocypris salinus, $H$. incongruens and Cypridopsis aculeata (Crustacea, Ostracoda) from Baltic brackish-water rockpools. Mar. Biol. 8:271-279.

Gerten D, Adrian R, 2002. Species specific response of freshwater copepods to recent summer warming. Freshwater Biol. 47:2163-2173.

Hairston NG Jr, 1998. Time travels: what's timely in diapause research. Arch. Hydrobiol. Spec. Issues Advanc. Limnol. $52: 1-15$.

Hairston NG Jr, Kearns CM, Ellner SP, 1996. Phenotypic variation in a zooplankton egg bank. Ecology 77:2382-2392.

Hairston NG Jr, Van Brut RA, Kearns CM, Engstrom DR, 1995. Age and survivorship of diapausing eggs in a sediment egg bank. Ecology 76:1706-1711.
Halbach U, 1973. Life table data and population dynamics of the rotifer Brachionus calyciflorus Pallas as influenced by periodically oscillating temperature, p. 217-288. In: W. Wieser (ed.), Effect of temperature on ectothermic organisms. Springer.

Havel JE, Talbott BL, 1995. Life history characteristics of the freshwater ostracod Cyprinotus incongruens and their application to toxicity testing. Ecotoxicology 4:206-218.

Hubbs C, 1964. Effects of thermal fluctuations on the relative survival of greenthroat darter young from stenothermal and eurythermal waters. Ecology 45:376-379.

Hulsmans A, Vanschoenwinkel B, Pyke C, Riddoch BJ, Brendonck L, 2008. Quantifying the hydroregime of a temporary pool habitat: a modelling approach for ephemeral rock pools in SE Botswana. Ecosystems 11:89-100.

Hutchinson GE, 1967. A treatise on Limnology. II. Introduction to lake biology and the limnoplankton. Wiley, New York: $1048 \mathrm{pp}$.

Ikeda T, 1992. Growth and metabolism of the hyperiid amphipod, Themisto japonica (Bovallius), reared in the fluctuating and constant temperatures in the laboratory J. Plankton Res. 14:925-935

Martins MJF, Vandekerkhove J, Namiotko T, 2008. Environmental stability and the distribution of the sexes: insights from life history experiments with the geographic parthenogen Eucypris virens (Crustacea: Ostracoda). Oikos 117:829-836.

McLay CL, 1978. The population biology of Cyprinotus carolinensis and Herpetocypris repatans (Crustacea, Ostracoda). Can. J. Zool. 56:1170-1179.

Meisch C, 2000. Freshwater Ostracoda. Spektrum Akademischer Verlag GmbH, Heidelberg: 522 pp.

Mezquita F, Roca JR, Wansard G, 1999. Moulting, survival and calcification: the effects of temperature and water chemistry on an ostracod crustacean (Herpetocypris intermedia) under experimental conditions. Arch. Hydrobiol. 146:219-238.

Montagnes DJS, Weisse T, 2000. Fluctuating temperatures affect growth and production rates of planktonic ciliates. Aquat. Microb. Ecol. 21:97-102.

Obedzinski M, Letcher BH, 2004. Variation in freshwater growth and development among five New England Atlantic salmon (Salmo salar) populations reared in a common environment. Can. J. Fish. Aquat. Sci. 61:2314-2328.

Orcutt JD Jr, Porter KG, 1983. Diel migration and thermal fluctuation in Daphnia magna. Limnol. Oceanogr. 28:720730 .

Otero M, Rossi V, Baltanás A, Menozzi P, 1998. Effect of genotype and photoperiod on diapause strategies in Eucypris virens (Jurine, 1820) (Crustacea: Ostracoda). Arch. Hydrobiol. Spec. Issues Advanc. Limnol. 52:229-236.

Pfrender ME, Deng HW, 1998. Environmental and genetic control of diapause termination in Daphnia. Arch. Hydrobiol. Spec. Issues Advanc. Limnol. 52:237-251.

Putnam HM, Edmunds PJ, Fan TY, 2010. Effect of a fluctuating thermal regime on adult and larval reef corals. Invertebr. Biol. 129:199-209.

Ripley BJ, Holtz J, Simovich MA, 2004. Cyst bank life-history model for a fairy shrimp from ephemeral ponds. Freshwater Biol. 49:221-231.

Roff DA, 1980. Optimizing development time in a seasonal en- 
vironment: the "ups and downs" of clinal variation. Oecologia 45:202-208.

Rossi V, Albini D, Benassi G, Menozzi P, 2012. To rest in hydration: hatching phenology of resting eggs of Heterocypris incongruens (Crustacea: Ostracoda). Fundam. Appl. Limnol. 181:49-58.

Rossi V, Bartoli M, Bellavere C, Gandolfi A, Salvador E, Menozzi P, 2004. Heterocypris (Crustacea: Ostracoda) from the Isole Pelagie (Sicily, Italy): hatching phenology of resting eggs. Ital. J. Zool. 71:223-231.

Rossi V, Benassi G, Belletti F, Menozzi P, 2011. Colonization, population dynamics, predatory behaviour and cannibalism in Heterocypris incongruens (Crustacea: Ostracoda). J. Limnol. 70:102-108.

Rossi V, Gandolfi A, Baraldi F, Bellavere C, Menozzi P, 2007. Phylogenetic relationships of coexisting Heterocypris (Crustacea, Ostracoda) lineages with different reproductive modes from Lampedusa Island (Italy). Mol. Phylogenet. Evol. 44:1273-1283.

Rossi V, Gandolfi A, Menozzi P, 1996. Egg diapause and clonal structure in partenogenetic populations of Heterocypris incongruens (Ostracoda). Hydrobiologia 320:45-54.

Rossi V, Menozzi P, 1990. The clonal ecology of Heterocypris incongruens (Crustacea: Ostracoda). Oikos 57:388-398.

Rossi V, Menozzi P, 1993. The clonal ecology of Heterocypris incongruens (Ostracoda): life-history traits and photoperiod. Funct. Ecol. 7:177-182.

Rossi V, Menozzi P, 2012a. Effects of mother presence and photoperiod on egg production and hatching of two asexual lineages of Eucypris virens (Crustacea: Ostracoda). Fundam. Appl. Limnol. 180:59-68.

Rossi V, Menozzi P, 2012b. Inbreeding and outbreeding depression in geographical parthenogens Heterocypris incongruens and Eucypris virens (Crustacea: Ostracoda). Ital. J. Zool. 79:259-267.

Rossi V, Tondelli B, Gandolfi A, Bellavere C, McKenzie KG, Menozzi P, 2003. Heterocypris (Crustacea: Ostracoda) from the Isole Pelagie (Sicily, Italy): population genetics. Ital. J. Zool. 70:101-108.

Scholnick DA, 1995. Sensitivity of metabolic rate, growth, and fecundity of tadpole shrimp, Triops longicaudatus, to environmental variation. Biol. Bull. 189:22-28.

Simovich MA, Hathaway SA, 1997. Diversified bet-hedging as a reproductive strategy of some ephemeral pool anostracans (Branchiopoda). J. Crustacean Biol. 17:38-44.

Stearns S, 1992. The evolution of life histories. Oxford University Press, New York: 249 pp.

Sweeney BW, Schnack JA, 1977. Egg development, growth, and metabolism of Sigara alternata (Say) (Hemiptera: Corixidae) in fluctuating thermal environments. Ecology 58:265-277.

Sywula T, Sell J, Wozniak G, Sobolewska A, 1991. Non-specific esterase polymorphism in marginal populations of Cyprinotus (Heterocypris) barbarus (Gauthier et Brehm) (Crustacea, Ostracoda). Bull. Pol. Acad. Sci. Biol. 39:353-362.

Thorp JH, Wineriter SA, 1981. Stress and growth response of juvenile crayfish to rhythmic and arrhythmic temperature fluctuations. Arch. Environm. Contam. Toxicol. 10:69-77.

Twombly S, Clancy N, Burns CW, 1998. Life history consequences of food quality in the freshwater copepod Boeckella triarticulata. Ecology 79:1711-1724.

UC IPM, 1990. Degree-days: single sine method, publication 9. Division of Agriculture and Natural Resources, University of California ed.

Vandekerkhove J, Matzke-Karasz R, Mezquita F, Rossetti G, 2007. Experimental assessment of the fecundity of Eucypris virens (Ostracoda, Crustacea) under natural sex ratios. Freshwater Biol. 52:1058-1064.

van Harten D, 1983. Resource competition as a possible cause of sex ratio in benthic ostracodes, p. 568-580. In: R.F. Maddocks (ed.), Applications of Ostracoda. University of Houston Publications.

Wilbur HM, Rudolf VHW, 2006. Life-History evolution in uncertain environments: bet hedging in time. Am. Nat. 168:398-411.

Winder M, Schindler DE, 2004. Climatic effects on the phenology of lake processes. Glob. Change Biol. 10:1844-1856.

Worner SP, 1992. Performance of phenological models under variable temperature regimes: Consequences of the Kaufmann or rate summation effect. Environ. Entomol. 21:689699. 